\title{
Environmental and economic assessment of the possibilities to increase the land preservation level in terms of open-pit mining
}

\author{
Yevheniy Babets ${ }^{1,}$, Yevheniy Terekhov ${ }^{2}$, Taras Mormul $^{3}$, Iryna Melnikova ${ }^{4}$, and Vitalina Komirna ${ }^{5}$ \\ ${ }^{1}$ Research Mining Institute of Kryvyi Rih National University, Department of Open-pit Mining, 11 Vitaly Matusevich Str, Kryvyi \\ Rih, 50027, Ukraine \\ 2 Dnipro University of Technology, Department of Applied Economics, Entrepreneurship, and Public Administration, 19 Dmytra \\ Yavornytskoho Av., Dnipro, 49005, Ukraine \\ ${ }^{3}$ Institute for Nature Management Problems and Ecology of National Academy of Sciences of Ukraine, Department of Natural Resources \\ of Environmental Technology Basics, 6 Volodymyra Monomaha Str., Dnipro, 49000, Ukraine \\ ${ }^{4}$ Kryvyi Rih National University, Department of Management and Administration, 11 Vitaly Matusevich Str, Kryvyi Rih, 50027, \\ Ukraine \\ ${ }^{5}$ European Social and Technology University, Faculty of Sociomedical Sciences, 26-610 Radom, Poland
}

\begin{abstract}
Conditions of the planning of open-pit mining objects have been identified, making it possible to reduce the need in the allotted land area during mineral extraction. The research results have allowed proposing a methodological approach to determine economic expediency of the increase in the technogenic land reclamation level under conditions of open-pit mining, being the reserves to expand the technogenic land areas returned to the economic use.
\end{abstract}

\section{General statement of the problem}

In Ukraine, level of land reclamation in terms of the land area disturbed by open-pit mining is not more than $50 \%$; the rest of the mining area is excluded from the economic use for decades or even for ever resulting in considerable losses for further land use in a mining region and leaving the unsolved problem of negative environmental impacts of mining activities. First of all, reclamation is topical for those mining areas requiring the lowest costs for their restoration. Due to the fact that a great share of the disturbed lands is not restored, a mining enterprise is to compensate the land owners their losses of land resources that form the grounds for conflicts related to the land allotment for mining purposes. Thus, current topical problem is to search for the possibilities to increase a specific land share to be restored in terms of a general area of mining allotment along with the substantiation of technological solutions to plan mining operations aimed at reducing the disturbed land area while mineral mining.

\section{Analysis of recent studies and publications}

Scientists, dealing with the problems of the reduction of mining-related environmental impacts, pay considerable attention to the development of ecological and economic criteria of administrative decision-making concerning mining object planning. Implementation of the measures for land reclamation after open-pit mining should favour the mining industry transfer into the sustainable mode.
That is the sustainable development of the mining sector which should be determinant for the activities related to the mineral use for national economy [1]. Thus, the development of main mining processes should be in compliance with the measures for the negative mining effects compensation in both environmental and social terms since negligence of the environmental-saving requirements is the reason of sharpening economic and social problems in the mining sector.

Source [2] indicates that mining effects on the environment should be overcome partially by creating investment-attractive technogenic lands and partially by activating the processes of natural self-restoration of the disturbed terrains. Nevertheless, following problem is still unsolved: what share of mining allotment should be covered with the lands to be returned for the economic use. It is obvious that it requires the elaboration of certain criteria to evaluate the expediency of restoration of specific mining objects in terms of the land use purposes.

Litvinov [3] highlights the necessity of such planning of mining objects in terms of which it will be possible to restore as many disturbed land areas as possible. According to the researcher, it is the level of lands under reclamation that should be one of the main criteria to evaluate the efficiency of different technological schemes for deposit mining.

However, a problem, concerning the following, still lacks its solution: evaluation of possibilities to improve the land preservation level in terms of open-pit mining at the expense of both limited shares of disturbed lands for the construction of open-pit mining objects and search for the resources to improve economic attractiveness of

\footnotetext{
* Corresponding author: ebabets@gmail.com
} 
disturbed land restoration according to the specific land use purposes.

Irrespective of the considerable scientific findings as for improving the efficiency of activities related to the restoration of environmental objects within the mining allotment area, insufficient attention has been paid to the identification of economically expedient reserves for the increase in mining-related land restoration according to the land disturbance. An issue concerning substantiation of technological schemes for planning mining objects in terms of land preservation criteria should be considered more as well.

The research objective is to substantiate theoretically the grounds and develop recommendations concerning the specification of technological trends in providing the limited disturbance of the mining allotment lands as well to assess economically expedient reserves of land reclamation for the areas disturbed while open-pit mining to reduce the land losses in terms of the land disturbance area.

\section{Statement of the main research material}

Mineral mining is still of high importance for the economic development of industrial countries. The mining sector is a factor for increasing a level of capital investment in tangible assets in all the technologically related industries; it favours overall economic growth of the countries with the developed mining sector [4].

However, planning of mining enterprises requires paying considerable attention to the development of measures to limit the mining impact on the environment. Those negative effects are inevitable; their amount depends on the demand for some specific products offered by the mining sector [5, p. 494].

Along with the economic effects from the deposit development, among other things, a society has environmental damages in the form of disturbed land resources. While accumulating at a certain level, the damages result in the necessary costs for their elimination, and the costs may exceed the effect of the mineral use [6].

Thus, legislation of the majority of mining countries obliges mining enterprises to restore the lands so that they will be of the same state before mining operations [7]. To do that, it is required to determine the factors stipulating the extent of mineral-mining land disturbance and identify the possibilities to implement economically expedient activities for technogenic land restoration.

Horizontal open-pit mining, resulting in more intense land disturbance in reliance on the mass unit of the extracted mineral, is of the highest loss for land resources and for the ecosystem in general. According to [8], constant tendency to open-pit operations is peculiar for current world mining development. There is about $73 \%$ of total mineral output extracted by open-pit mining worldwide. In its turn, surface mining development is accompanied by the increasing concentration of production, deepening open pits, and, correspondingly, volumes of the rock mass removal. Open-pit mining is mostly used to extract ore minerals, lignite, rock for construction materials, kaolin, rare earth metals etc. In terms of Ukraine, about $75 \%$ of mineral output is extracted by open-pit mining. As for the iron-ore industry, the figure is $85 \%$ [9, p. 1]. For instance, Dnipropetrovsk region encloses 100 open pits and mines. Total area of the disturbed land within the region is 27 thousand ha.

Generally, each million tons of the extracted manganese ore result in the disturbance of more than 600 ha of land. In case of iron ore, the figure is 640 ha; coal up to $43 \mathrm{ha}$, and non-metallic minerals - up to 580 ha. If the open pit depth is down to $150 \ldots 200 \mathrm{~m}$, then about 100 ha are to be disturbed totally with the formation of the mined-out space. If the open pit depth is $450 \mathrm{~m}$, more than 250 ha are to be disturbed [10]. To fill that space, about $80 \mathrm{mln} \mathrm{m}^{3}$ of the overburden rock are required. Analysis of international practice shows that even in terms of the involved cutting-edge technologies, the most efficient land restoration is impossible if there is no economic motivation. In this context, Table 1 represents the balance of mining land use in Rhine lignite basin as of the late 2012.

Table 1. Balance of the land use areas in Rhine lignite basin $[11$, p. 41]

\begin{tabular}{|c|c|c|c|}
\hline $\begin{array}{c}\text { Area of } \\
\text { allotment, } \\
\text { ha }\end{array}$ & $\begin{array}{c}\text { Area of } \\
\text { restored } \\
\text { lands, } \\
\text { ha/\% }\end{array}$ & $\begin{array}{c}\text { Including the land } \\
\text { area restored for } \\
\text { agricultural } \\
\text { purposes, ha/\% }\end{array}$ & $\begin{array}{c}\text { Area of } \\
\text { disturbed } \\
\text { land, ha }\end{array}$ \\
\hline 31512,2 & $\begin{array}{c}22248.4 / \\
70.6 \%\end{array}$ & $11839.2 / 53.2 \%$ & $\begin{array}{c}9265.8 / 29.4 \\
\%\end{array}$ \\
\hline
\end{tabular}

Land losses in German are mostly tried to be cut by reducing the environmental hazard of land use and by developing environmentally non-exhausting types of land use. However, considerable share of technogenic terrains is still inaccessible for public. To reduce land losses due to mining objects, certain technological solutions should be approved and measures should be taken to create the most favourable conditions for further land reclamation for the lands which disturbance is inevitable right at the stages of open pit planning, stripping operations, and mining operations.

Technological objects, which location required natural land allotment, are demonstrated schematically in Fig. 1. Depending on the mineral type to be mined and the appropriate deposit mining scheme, different land areas are subject to disturbance (Table 2). Thus, it is possible to have certain effect on general land disturbance area in terms of mining allotment at the level of technological solutions as for the mining object planning (e.g. by internal waste dumping as opposite to external waste dumping, transfer of the transportation routes inside the open-pit field etc.).

Thus, while developing a manganese-ore deposit and depending on the occurrence depth of the ore deposit, it is required to have $163 \ldots 228$ ha of natural lands for stripping and dumping. According to the open pit objects, that area is distributed as follows: permanent trench $3.5 \ldots 4.5 \%$; transport incline $-8.6 \ldots 8.4 \%$; working trench $-57.0 .56 .1 \%$; and construction waste dump $-31.0 \%$. Consequently, the majority of residual mine workings 
(about 90\%) is accounted for the working trench and construction waste dump.

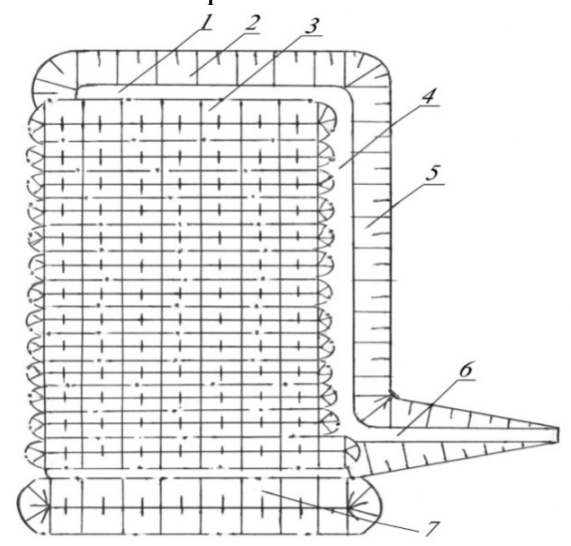

Fig. 1. Schematic of technological structure of open pits while developing a horizontal deposit: 1 - residual mined-out space; 2 - mining flank of an open pit; 3 - internal waste dump; 4 transport incline; 5 - non-mining flank of an open pit; 6 permanent trench; 7 - construction waste dump.

Reserves of the land area reduction should be determined by optimizing parameters of land allotment for the open-pit technogenic objects. In their turn, the parameters depend on the geometry of the open-pit field, system of its stripping and mining. Degree of the land resources use is defined by the ratio of the areas of lands being returned and lands being allotted for technological open pit objects during all the deposit mining stages. Such an approach makes it possible to determine the reserves of land resources preservation by reducing the area of land allotment to the scientifically substantiated standards and by increasing the areas of restored sites within each of the mentioned technological objects.

Losses of land resources $\Pi_{3}$ due to the open pit objects are the target function of the parameters $\mathrm{S}_{\mathrm{Hi}}, \mathrm{S}_{\mathrm{pi}}, \mathrm{S}_{\mathrm{H}}$, being formed during all the stages of deposit development. In general, the function may be represented as follows:

$$
\Pi_{3}=f(B, L, \Phi, \Gamma, \Pi, T, C, P) \quad \min
$$

where $B, L, \Phi$ is width, length, and shape of the open-pit field respectively; $\Gamma$ is mining and geological conditions of the ore deposit occurrence; $\Pi$ is technological parameters of the formation of an open-pit working zone; $T$ is technical facilities for production processes; $C$ is stripping and mining system for the deposit; and $P$ is topography of the mining allotment area.

Table 2. Distribution of the land allotment area in terms of technogenic objects of a manganese open pit [12]

\begin{tabular}{|c|c|c|c|c|c|c|c|}
\hline \multirow{2}{*}{$\begin{array}{c}\text { Open pit } \\
\text { depth, } \mathbf{m}\end{array}$} & $\begin{array}{c}\text { Area of the } \\
\text { permanent trench on } \\
\text { top, ha }\end{array}$ & $\begin{array}{c}\text { Area of the } \\
\text { transport incline on } \\
\text { top, ha }\end{array}$ & $\begin{array}{c}\text { Area of the working } \\
\text { trench on top, ha }\end{array}$ & $\begin{array}{c}\text { Construction waste dump } \\
\text { height, } \\
\text { m }\end{array}$ & $\begin{array}{c}\text { base } \\
\text { width, } \mathbf{m}\end{array}$ & $\begin{array}{c}\text { Total } \\
\text { area, hamp }\end{array}$ & $\begin{array}{c}\text { Totlotment } \\
\text { area, ha }\end{array}$ \\
\hline 50 & $5.6 / 3.4^{*}$ & $14.1 / 8.6$ & $93.0 / 57.0$ & 73 & 253 & $50.6 / 31.0$ & 163.3 \\
\hline 60 & $7.8 / 4.0$ & $16.6 / 8.5$ & $110.5 / 56.4$ & 88 & 304 & $61.0 / 31.0$ & 195.9 \\
\hline 70 & $10.3 / 4.5$ & $19.1 / 8.4$ & $127.9 / 56.1$ & 101.7 & 352 & $70.5 / 30.9$ & 227.8 \\
\hline
\end{tabular}

Note: numerator - total area of the mining allotment, ha; denominator - share in \% within the total allotment area.

Identification of the land preservation reserves should rely on the development of mining technologies, rational selection of the striping and dumping parameters. It means that nowadays reserves of the reduction of land resource losses are connected first of all with reaching the parameters of open-pit technological objects. Development of current technologies and mining systems for certain deposits should be oriented to the rejection of a fixed transport incline along with the search for possibilities to form mostly internal waste dumps.

Basing on the expression (1), reserves for reducing losses of land resources are connected with the parameters of technological objects of a mining enterprise. Thus, the objects are to be designed taking into consideration their location on the earth's surface. In general, rational land use parameters are stipulated by certain ratio between the parameters of operating objects and their elements as well as other objects in the context of mining and concentration complex, when the lowest land capacity $3_{e}$ and the highest reclamation coefficient $K_{p}$ are reached.

According to the rates of ore bed mining, the internal waste dumps are restored and returned for their further use; here, there are no technological problems. There are other solutions in case of using the residual mine workings and construction mine dump. They can be filled and reclaimed mostly when the deposit is mined out; that is due to a great volume of labour-intense and costly operations. The operating mining and concentration complexes use land resources at the level of theoretical land capacity. As for reclamation of the mined-out land, it is performed within the considerably smaller areas comparing to the potential ones; that is due to the necessity of significant costs for overburden removal for filling the working trench.

To specify the main parameters of technological objects to mine horizontal deposits that stipulate the losses of allotted land areas, the report data of mining and engineering reclamation of lands within the manganese open pits of Pokrovskyi mining and concentration complex (PGZK) have been analyzed. Effect of the area of open-pit field $S_{\text {B.o }}$, area of the residual mine workings $S_{B}$, coefficient of reclamation $K_{p}$, and land capacity $3_{\mathrm{e}}$ upon the land losses $\Pi_{3}$ has been considered. The mentioned parameters have been taken into account in terms of each open pit and on average in terms of the complex (Table 3). Following equation of regression is obtained for the statistic data represented in Table 3:

$$
\Pi_{3}=26.4+0.0008 S_{\kappa}-0.0026 S_{6}-33.8 K_{p}+0.213_{e}, \text { ha/mln t of ore. }
$$


Table 3. Land use in terms of open-pit fields of Pokrovskyi GZK.

\begin{tabular}{|l|c|c|c|c|c|c|}
\hline \multicolumn{1}{|c|}{ Open pit } & $\begin{array}{c}\boldsymbol{S}_{\boldsymbol{\kappa}}, \\
\text { ha }\end{array}$ & $\begin{array}{c}\boldsymbol{S}_{\boldsymbol{6} . \boldsymbol{o}}, \\
\mathbf{H a}\end{array}$ & $\begin{array}{c}\boldsymbol{S}_{\boldsymbol{s}}, \\
\mathbf{h a}\end{array}$ & $\begin{array}{c}\boldsymbol{K}_{\boldsymbol{p}}, \\
\mathbf{h a} / \mathbf{h a} \mathbf{c}\end{array}$ & $\begin{array}{c}3_{\boldsymbol{e}}, \\
\mathbf{h a} / \mathbf{m l n} \mathbf{t} \text { of ore }\end{array}$ & $\begin{array}{c}\boldsymbol{\Pi}_{\boldsymbol{3}}, \\
\mathbf{h a} / \mathbf{m l n} \mathbf{t} \text { of ore }\end{array}$ \\
\hline Alexandrovsky & 904 & 735 & 169 & 0,81 & 44,10 & 8,25 \\
\hline Bogdanovsky & 1335 & 765 & 570 & 0,57 & 27,53 & 11,76 \\
\hline Zaporizhzhya & 1320 & 800 & 520 & 0,61 & 30,7 & 12,10 \\
\hline Shevchenkovsky & 1637 & 1263 & 374 & 0,77 & 29,02 & 6,62 \\
\hline Pivnichnyi & 1510 & 1050 & 460 & 0,70 & 31,92 & 9,47 \\
\hline Chkalovskyi-1 & 1182 & 771 & 411 & 0,65 & 34,36 & 11,96 \\
\hline Chkalovskyi -2 & 1796 & 976 & 820 & 0,54 & 30,13 & 13,77 \\
\hline Pokrovskyi & 700 & 556 & 144 & 0,79 & 21,67 & 4,46 \\
\hline Average of PGZK & 1298 & 864 & 433 & 0,68 & 31,18 & 9,80 \\
\hline
\end{tabular}

The equation does not contain $\mathrm{S}_{\text {в.о }}$; it shows that there is no connection between land loss and area of internal waste dumps. Such a conclusion can be explained by the fact that the internal waste dumps are formed throughout the whole open pit area, and its effect on the land loss is considered with the help of parameter $S_{\kappa}$. Adequacy of each of equation regressors (2) has been defined with the help of Student statistic t. During the comparison with table values $t=3.18$ for the number of degree of freedom $\mathrm{n}=3$, regressor $\mathrm{S}_{\mathrm{B}}$ has the lowest adequacy. It means that the area of residual mine workings has minor effect on the loss value $\Pi_{3}$ in the mining allotment, and this parameter may be also excluded from the regression model. Thus, we obtain the equation:

$$
\Pi_{3}=26.4+0.0008 S_{K^{-}}-33.8 K_{p}+0.213_{\mathrm{e}}, \mathrm{ha} / \mathrm{mln} \mathrm{t} \text { of ore. }
$$

If statistic value is $t=2.78$, all the regressors of equation (3) are significant, and the resulting feature $\Pi_{3}$ is closely connected with the factor features $S_{\kappa}, K_{p}$, and $3_{e}$
$\left(\mathrm{R}^{2}=0.98\right)$, which, according to Fisher's ratio test, represent adequately their influence on the result $(\mathrm{F}=61.1)$.

Thus, it can be concluded that the value of the land losses in terms of open-pit mining is stipulated first of all by the open-pit field area, coefficient of reclamation, and land capacity of the mining operations. Consequently, it is possible to reduce overall level of land losses for mining enterprises by increasing the level of land reclamation in terms of the area of land disturbance, by the development of mining technology towards the reduced external dumping, and by the creation of more favourable conditions to restore technogenic lands.

It is necessary to spend different sum of money for the reclamation of mining objects; correspondingly, that causes unequal motivation to the formation of certainpurpose lands within the territory of a specific mining object. Table 4 show classification of the open-pit mining objects according to the economic expediency of their reclamation for economic purposes.

Table 4. Classification of the open-pit mining objects according to economic expediency of their restoration for economic purposes

\begin{tabular}{|c|c|c|c|}
\hline Object & $\begin{array}{l}\text { Ratio in the mining } \\
\text { allotment area, \% }\end{array}$ & Location of the object & Characteristics* \\
\hline $\begin{array}{c}\text { Internal waste } \\
\text { dumps }\end{array}$ & $38 \ldots 40$ & Surfaces of the internal waste dumps & \multirow{3}{*}{$\begin{array}{l}\text { The lands are subject to mining and } \\
\text { engineering as well as biological reclamation }\end{array}$} \\
\hline \multirow{3}{*}{$\begin{array}{l}\text { Construction } \\
\text { waste dump }\end{array}$} & \multirow{3}{*}{$30.5 \ldots 31.5$} & Surfaces of the external waste dumps & \\
\hline & & Surfaces of the washery refuse storage & \\
\hline & & $\begin{array}{l}\begin{array}{l}\text { Surfaces of the slopes of external waste } \\
\text { dumps }\end{array} \\
\end{array}$ & The lands are irretrievably lost for agriculture \\
\hline $\begin{array}{c}\text { Transport incline } \\
\text { on top }\end{array}$ & $8 \ldots 9$ & $\begin{array}{l}\text { Sites for transportation communications } \\
\text { (automobile and railway roads, electric } \\
\text { networks) }\end{array}$ & $\begin{array}{l}\text { The lands are subject to reclamations upon the } \\
\text { condition that the mentioned objects are } \\
\text { liquidated }\end{array}$ \\
\hline \begin{tabular}{|c|}
$\begin{array}{l}\text { Working trench } \\
\text { on top }\end{array}$ \\
\end{tabular} & $16 \ldots 17$ & Surface of the residual working trench & $\begin{array}{l}\text { The lands are not subject to reclamation for } \\
\text { agricultural purposes }\end{array}$ \\
\hline Permanent trench & $3 \ldots 4.5$ & $\begin{array}{l}\text { Surfaces of the external transport } \\
\text { (permanent) trenches }\end{array}$ & $\begin{array}{l}\text { The lands can be restored in case of economic } \\
\text { expediency by using fertile soil from other } \\
\text { open pits }\end{array}$ \\
\hline
\end{tabular}

Note*: made up involving the data from source [13].

Thus, there are the surfaces of external waste dump slopes and partially the surfaces of external transport (permanent) trenches which are the territories being often left without any reclamation. However, expediency of land restoration should be determined by the ratio of costs for land reclamation according to certain economic purpose and market monetary estimation of the reclaimed lands, being represented by the following expression:

$$
\mathrm{K}_{\mathrm{ei}}=\frac{\bigsqcup_{3 \mathrm{i}}}{\mathrm{B}_{\Gamma \mathrm{i}}+\mathrm{B}_{\mathrm{Pi}}+\mathrm{B}_{\mathrm{Bi}}+\mathrm{B}_{\mathrm{K} . \Omega}+\mathrm{B}_{\text {pem.i }}},
$$

where $K_{\mathrm{ei}}$ is coefficient of efficiency of costs for land reclamation in terms of $i^{\text {th }}$ reclamation purpose; $\bigsqcup_{3 i}$ is market monetary estimation of a unit of the restored land in terms of $i^{\text {th }}$ reclamation purpose; $\mathrm{B}_{\Gamma \mathrm{i}}, \mathrm{B}_{\mathrm{Pi}}, \mathrm{B}_{6 \mathrm{i}}$ are losses for mining and engineering as well as biological 
reclamation and maintenance within the land area in terms of $i^{\text {th }}$ reclamation purpose respectively; $B_{\text {к.я }}$ is payment for the deteriorated quality of the land reclaimed in terms of $\mathrm{i}^{\text {th }}$ reclamation purpose; and $\mathrm{B}_{\text {рем.i }}$ is costs for repair operations due to land restoration.

The highest value $K_{\mathrm{ei}}$ will stimulate for more complete restoration of the technogenically disturbed lands. However, if the degree of land surface disturbance requires growing costs for reclamation (first of all, for agricultural purposes), that will reduce motivation to reclaim corresponding mining objects. As a result, technogenic lands are of nonuniform structure, being the combination of reclaimed sites and the sites left without any reclamation due to their more serious disturbance. Generally, land reclamation for agricultural purposes is the most costly one, and market value of those lands in Ukraine is reduced (Fig. 2).

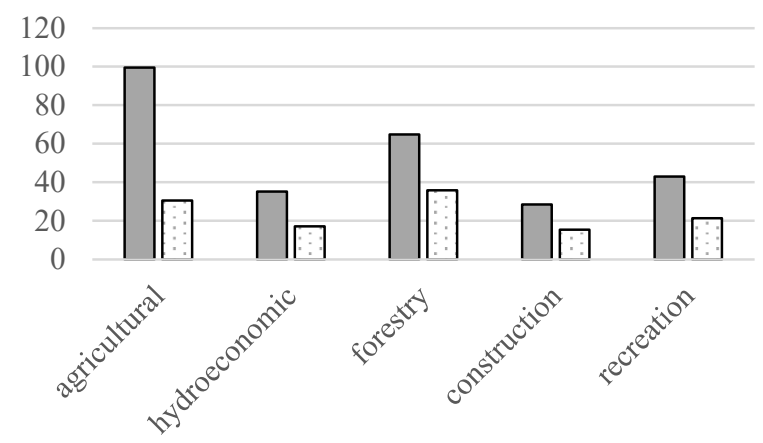

$\square$ Costs for Landreclamation, UAH thousand/ha $\square$ market value of the reclaimed land, UAH thousand/ha

Fig. 2. Ratio of costs for reclamation and standard monetary estimates of technogenic lands in terms of land use purpose.

Market value of the land is defined by actual state of supply and demand for the land; it is specified upon consultation between the sales parties. At the same time, liquidation of different technological mining-related objects will require different costs per unit of the reclaimed area. From the viewpoint of cost cutting, a mining enterprise is interested in reclamation of nothing but the sites where the highest coefficient of efficiency of reclamation costs will be obtained. Only the changing land purpose will make it possible to consider the sites being unattractive for agricultural-purpose reclamation as the ones which reclamation may provide the appropriate degree of efficiency. Thus, depending on the land reclamation purpose, economically expedient reserves of land restoration throughout the disturbance area will experience certain changes (Table 5).

The lowest costs for land reclamation are meant for hydroeconomic and forestry purposes; in their case, the requirements concerning soil quality and land topography relative to technogenic terrains are not so strict. For instance, a depression in the land surface, being the result of mineral extraction, may be fit for a reservoir as that depression favours the accumulation of water resources. Combination of hydroeconomic and forestry purposes for land reclamation makes it possible to restore practically all area of mining allotment.

Correspondingly, combination of different land use types will help replace the purposes of land reclamation with one another, if some purpose turns to be inexpedient; thus, there will be possible to use land reclamation reserves to the maximum. The most disturbed sites should be allotted for natural process of self-restoration with the preliminary measures for their chemical purification. In the context of reclaimed lands, it is possible to use $10 \ldots 15 \%$ of the mining area for that purpose. At the same time, land reclamation for the forestry purposes will make it possible to activate soil-forming processes and favour the preservation of nutrients in the soil thickness.

Land reclamation performed timely and properly will be the basis for further land use for the post-industrial purposes. However, it is more important to have such planning of mining operations which will allow reducing the need of a mining enterprise in the involvement of land resources in mineral mining. That will be possible owing to the selection of proper technological schemes of stripping, mining, and cleaning-up of an open-pit field from the viewpoint of total area of land disturbance by a mining enterprise.

Table 5. Economically expedient reserves of land reclamation in terms of open-pit mining.

\begin{tabular}{|c|c|c|}
\hline $\begin{array}{c}\text { Reclamation } \\
\text { purpose }\end{array}$ & $\begin{array}{c}\text { Economically expedient reserves of } \\
\text { land reclamation }\end{array}$ & Mining objects to be reclaimed \\
\hline Agricultural & $60 \ldots 70 \%$ of the disturbed area & Internal and construction waste dumps \\
\hline Forestry & $78 \ldots 80 \%$ of the disturbed area & $\begin{array}{c}\text { Internal and construction waste dumps, transport incline and permanent } \\
\text { trenches on top }\end{array}$ \\
\hline Construction & $70 \ldots 80 \%$ of the disturbed area & Internal and construction waste dumps, transport incline on top \\
\hline Hydroeconomic & $30 \%$ of the disturbed area & Working and permanent trenches, transport incline \\
\hline Sanitary & $60 \%$ of the disturbed area & Internal waste dumps, working trench, and transport incline on top \\
\hline Recreation & $90 \%$ of the disturbed area & $\begin{array}{c}\text { Internal and construction waste dumps, working and permanent } \\
\text { trenches, transport incline }\end{array}$ \\
\hline Succession & $100 \%$ of the disturbed area & $\begin{array}{c}\text { Internal waste dumps, construction waste dump, transport incline on } \\
\text { top, working trench on top, permanent trench }\end{array}$ \\
\hline
\end{tabular}

Basing on the results of the carried out research [2], certain technological solutions to mine the PGZK operating open pits have been proposed. While analyzing land resources from the viewpoint of market conditions of the mining enterprise economy, following parameters are 
proposed to assess the efficiency of the technological solutions:

1) Economic expediency of land preservation that characterizes a level of value conservation (monetary value) of natural lands:

$$
E_{\text {3.c }}=\frac{100 \cdot Ц_{p}\left(1-\Pi_{3 . p}\right)}{\bigsqcup_{n p}}, \%,
$$

where $\iota_{p}, L_{n p}$ is monetary value of the reclaimed and natural (undisturbed) lands respectively, UAH/ha; and $\Pi_{\text {3. } p}$ is losses of land resources in terms of the area, a unit share;

$$
\Pi_{\text {3.p }}=\frac{\left(1-K_{p}\right) \cdot 5_{n p}}{E_{p}} \text {, unit share; }
$$

where $E_{n p}, E_{p}$ is bonitet (quality) of the natural and reclaimed lands respectively, $\%$; and $K_{p}$ is coefficient of reclamation (a unit share);
2) Economic expediency of land reclamation as a payback parameter for the reclamation costs:

$$
E_{p}=\frac{100 \cdot Ц p \cdot\left({ }_{p}\right) \cdot K_{p}}{B}, \%,
$$

where $L_{p}\left(\zeta_{p}\right)$ is monetary estimation of the reclaimed lands according to their bonitet, $\mathrm{UAH} / \mathrm{ha}$; and $B_{p}$ is reclamation prime cost of the disturbed lands, $\mathrm{UAH} / \mathrm{ha}$;

Along with the use of those parameters, Table 6 represents technological approaches aimed at reduction of natural land areas being used and at the creation of favourable conditions for mining and engineering reclamation as well as increase in the land areas returned to the national economy. Firstly, that objective was reached by considering the possibility to locate stripping mine workings in the middle of an open-pit field; secondly, it was reached by changing the procedure of advance of the working front of stripping, extracting, and dumping benches along with the location of the stripping

\begin{tabular}{|c|c|c|}
\hline Technological approach & $\begin{array}{c}\text { Conditions of the technological scheme } \\
\text { application }\end{array}$ & Land-preservation efficiency \\
\hline $\begin{array}{l}\text { Filling the gap between the edge of } \\
\text { the working trench and slope of the } \\
\text { external waste dump }\end{array}$ & $\begin{array}{l}\text { Stage of open pit construction; depth of mineral } \\
\text { seam occurrence is } 10 \ldots 40 \mathrm{~m} \text {; seam thickness is } \\
\text { compared to the stripping thickness. High-capacity } \\
\text { transportation and dumping facilities. }\end{array}$ & $\begin{array}{l}\text { The mining allotment area for construction } \\
\text { waste dump is reduced by } 12.8 \text { ha; } \\
\text { reclamation costs are cut by UAH } 1034 \\
\text { thousand. }\end{array}$ \\
\hline Using internal permanent trenches & $\begin{array}{l}\text { Stage of construction; ramps are located along the } \\
\text { working trench length. Open pit depth is down to } \\
100 \mathrm{~m} \text {. Low-capacity transportation means for } \\
\text { cyclic mining operations. }\end{array}$ & $\begin{array}{l}\text { The mining allotment area for open pit } \\
\text { construction is reduced by } 20 \ldots 25 \text { ha; that } \\
\text { results in the compensation payments cut by } \\
\text { UAH } 4000 \text { thousand. }\end{array}$ \\
\hline $\begin{array}{l}\text { Basing on changes in the procedure } \\
\text { of open-pit field mining: } \\
\text { - combining the mined-out space } \\
\text { with the transport incline } \\
\text { - reclamation of mine workings in } \\
\text { terms of the external transport } \\
\text { incline } \\
\text { - combination and reclamation of } \\
\text { the residual mined-out space in } \\
\text { terms of the external transport } \\
\text { incline }\end{array}$ & $\begin{array}{l}\text { Stages of construction and operation. Mining of two } \\
\text { adjacent open pit fields or one field by blocks. } \\
\text { Stripping thickness is not more than } 50 \mathrm{~m} \text {. High- } \\
\text { capacity transportation and dumping facilities. At } \\
\text { all the operation stages. Mining of two adjacent } \\
\text { open pit fields or one field by blocks. Open pit depth } \\
\text { is } 50 \ldots 70 \mathrm{~m} \text {. Stripping shovels - draglines, motor } \\
\text { transport for mineral blocks. } \\
\text { Construction and operation stages. } \\
\text { Open pit depth is } 50 \ldots 70 \mathrm{~m} \text {. } \\
\text { Cyclic mining and transportation facilities. }\end{array}$ & $\begin{array}{l}\text { Surface of the residual mine workings } \\
\text { decreases by } 45 \ldots 103 \text { ha. Costs to } \\
\text { compensate agricultural losses are reduced } \\
\text { by UAH } 67200 \ldots 94200 . \\
\text { Complete filling of the residual mine } \\
\text { workings. Land disturbance decreases by } \\
112 \ldots 147 \quad \text { ha, costs to compensate } \\
\text { agricultural losses are reduced by UAH } \\
10048 \text { thousand } \\
\text { Land disturbance decreases by } 112 \ldots 157 \\
\text { ha. } \\
\text { Costs to compensate agricultural losses are } \\
\text { UAH } 67.2 \ldots 94.2 \text { thousand, costs for mining } \\
\text { and technical reclamation are cut by UAH } \\
7168 \ldots 10048 \text { thousand. } \\
\text { Economic efficiency of reclamation grows } \\
\text { from } 10.6 \% \text { up to } 13.1 \% \text {. }\end{array}$ \\
\hline $\begin{array}{l}\text { Basing on the division of an open- } \\
\text { pit field into two blocks (sites) }\end{array}$ & $\begin{array}{l}\text { Stage of clearing-up. Depth of the open pit is } 40 \ldots \\
60 \mathrm{~m} \text {. Length of the working trench is } 1.5 \ldots 2 \mathrm{~km} . \\
\text { Reduced open-pit mineral output. High-capacity } \\
\text { transportation and dumping facilities. }\end{array}$ & $\begin{array}{l}\text { The surface area of the residual mined-out } \\
\text { space for reclamation experiences two-fold } \\
\text { increase. In terms of Chkalovskyi open pit, } \\
\text { the surface increases by } 159.2 \text { ha. }\end{array}$ \\
\hline
\end{tabular}
mine workings relative to one another.

Table 6. Conditions of the use of technological schemes while mining horizontal deposits.

Thus, preservation of land resources is connected with the dimensions of stripping workings and waste dumps, places of their locations as well as the direction of front advancing of mining operations within the open-pit field. Consequently, selection of certain mining system determines the cutting method and limits the number of technologically possible and economically expedient technological systems of deposit mining.

\section{Conclusions and prospects of the research development}

1. Planning of the open-pit mining objects should involve the implementation of those technological schemes which make it possible to avoid additional land disturbance and preserve the planned output according to the demand for 
mineral. It has been specified that it is the selected mining system and technological scheme of stripping operations (i.e. parameters of permanent, transport, and working trenches) of the open-pit field which are of essential effect on the amount of disturbed lands of mining allotment. According to that fact, technological approaches have been proposed concerning the change in parameters of technological objects within the open-pit field aimed at reduction of the disturbed land area.

2. A criterion has been offered to identify economic expediency of land reclamation in terms of economic purposes. It has been determined that economic expediency of the disturbed land reclamation will depend on the degree of land surface disturbance within the mining allotment and purpose of its restoration. Economically expedient reserves of technogenic land reclamation in terms of open-pit mining should be specified by the most favourable ratio between the expected market value of the reclaimed lands and total costs for their reclamation disturbed by open-pit mining, basing on the classification of technogenic mining objects as for their suitability for reclamation at the economically attractive level.

3. There is the following prospective issue for further research in terms of the outlined problem: quantitative estimation of the amounts of value losses reduction for land resources resulting from the implementation of technological schemes of deposit mining in the context of land preservation.

\section{References}

1. J. Dubiński. Journal of Sustainable Mining Volume 12, 1, P 1-6 (2013)

2. Landinanspruchnahme und Wiedernutzbarmachung - Leitbilder für neue Landschaften: http://www.forschungsstellerekultivierung.de/hinter grundinformationen/archiv/kongress/einfuehrung.ht $\underline{\mathrm{ml}}$ (2018) Accessed 12 june 2018.

3. Y. Litvinov Geot. mech: inter-institutional collec. of scien. Pap. 126, P 81-91 (2016)

4. Y. Lei, N. Cui, D. Pan. Resources Policy 38, P 448457 (2013).

5. J. Jeswiet. Procedia CIRP 62, P 494-499 (2017)

6. L. Mancini, S. Sala. Resources Policy 57, P 98-111 (2018)

7. J. Howieson, H. Calmy, N. Ballard, P. Skinner, G. WO'Hara, L. Skinner, K. X. Ruthrof, R. Swift, V. Ballard $^{\mathrm{a}}$, G. E. St Hardy The Extractive Industries and Society. 4, P 290-299 (2017)

8. T. Kovalchuk Ukrainian journal on the problems of labour http://nbuv.gov.ua/UJRN/Ujpmp_2013_3_2

9. Y.Grygoriev. Messenger of Kryvyi Rih National University: collection of scientific papers. 34, P 266270 (2013)

10. Gumenyk I.L., Korsunskyi G.Ya., Lozhnikov O.V. Open-pit mining technology for gently-sloping mineral deposits. Dnipro, NMU (2014)
11. Mit Baumhäusern gegen Bagger. Geschichten vom Widerstand im rheinischen Braunkohlerevier Verlag: Packpapier; (2015).

12. V. Prokopenko, T. Mormul. Messenger of NTUU "PKI". Series "Mining". 21, P. 190-197 (2011)

13. V. Prokopenko, A. Cherep, Metallurgical and metal mining industry.. 4, P. 101-105 (2015) 